\title{
Penerapan Pembelajaran Strategi Problem Based Learning (PBL) untuk Meningkatkan Keaktifan dan Hasil Belajar IPA/Biologi Bagi Siswa Kelas XI Ak 1 SMK Negeri 1 Banyudono Kabupaten Boyolali Semester Genap Tahun Ajaran 2011/2012
}

\author{
IKA SRI SULASTRI \\ SMK N 1 Banyudono, Jl. Kuwiran No. 3 Banyudono, Boyolali, Indonesia \\ *email: sulastri_ika@yahoo.co.id
}

Manuscript received: 11 Desember 2014 Revision accepted: 1 Februari 2015

\begin{abstract}
In the classroom action research conducted has the goal that the implementation of the strategy learning model Problem Based Learning (PBL) can be used to enhance the activity and student learning outcomes. Implementation of classroom action research design was used classroom action research conducted by two cycles, each cycle consisting of 4 meetings, with research subjects Class XI AK 1 number of 40 students. Implementation of each cycle in the study consisted of four phases, namely: an action plan (Planning), action (acting), Observing and reflecting. Data collection activity of students in the application of strategic learning model Problem Based Learning (PBL), using observation techniques and data used as documentation of the final value. Research data analysis techniques are used as the final value of classical learning completeness of the final value. The calculation result obtained before the first cycle of learning outcomes with the lowest and highest 55, 90, 92.5\% completeness study. After the first cycle of learning results obtained with the lowest value of 60 and 90 with the highest passing grade of $95 \%$, after the second cycle study results obtained with the lowest value of 80 and the highest 100 with a $100 \%$ mastery learning. While active students in the first cycle of $69.2 \%$ and the second cycle by $76,3 \%$. With Action Research Classroom teachers can develop a variety of learning methods one with "Implementation model of strategic learning Problem Based Learning (PBL) which can be used as an attempt to enhance the activity and the learning outcomes of students of class XI AK 1, in SMK Negeri 1 Banyudono, Boyolali, even semester Academic Year 2011/2012".
\end{abstract}

Keywords: learning strategies Problem Based Learning (PBL), activeness and student learning outcomes

\section{LATAR BELAKANG}

Berdasarkan hasil belajar kelas XI AK 1 SMK Negeri 1 Banyudono Kabupaten Boyolali pada semester gasal tahun 2011/2012 pada mata pelajaran IPA / Biologi masih rendah dengan jumlah siswa 40 orang. Hal ini dibuktikan dengan nilai yang dicapai siswa kelas XI AK 1 pada hasil ujian atau ulangan akhir semester (UAS) gasal yang mencapai nilai di atas batas ketuntasan 65 mencapai $87,5 \%$ selebihnya jauh dibawah batas ketuntasan. Selain itu dari hasil observasi pada awal semester genap awal bulan Januari 2012 yang dilakukan di SMK Negeri 1 Banyudono pada kelas XI AK 1, ditemukan beberapa kelemahan atau kendala pembelajaran, antara lain: siswa mengalami kejenuhan, siswa cenderung pasif, hasil belajar kurang standar KKM yaitu $<65$, kurang berani dalam mengungkapkan pendapat, jawaban maupun mengajukan pertanyaan; Kelemahan atau kendala pembelajaran tersebut dapat diatasi dengan menggunakan metode pembelajaran yang tepat.

Proses pembelajaran IPA/Biologi yang selama ini berlangsung di SMK N 1 Banyudono pada proses pembelajaran KBM yang terjadi masih banyak berfokus kepada guru sebagai sumber utama pengetahuan (transfer pengetahuan dari guru ke siswa). Ternyata hal ini merupakan salah satu kelemahan proses pembelajaran. Bertolak dari beberapa kendala tersebut, peneliti menerapkan penggunaan metode pembelajaran untuk meningkatkan keaktifan dan hasil belajar siswa. Metode pembelajaran yang dimaksud dengan menggunakan strategi Problem Based Learning (PBL). Strategi pembelajaran Problem Based Learning merupakan suatu pendekatan pengajaran yang menggunakan masalah dunia nyata sebagai suatu konteks bagi siswa untuk belajar cara berpikir kritis dan keterampilan memecahkan masalah, serta untuk memperoleh pengetahuan dan konsep yang esensial dari materi pelajaran (Nurhadi, 2004:109).

Siswa SMK dalam perkembangannya telah mampu berpikir operasional serta lebih afektif dan kreatif. Perkembangan kognitif siswa SMK kelas XI sudah berada pada tahap operation konkrit ke formal operation. Pada tahap ini siswa sudah berpikir logis, siswa juga sudah mulai berani untuk berpendapat dan sudah mulai mengerti arti pentingnya sebuah kebersamaan. Pembelajaran berbasis masalah (PBL) diharapkan dapat meningkatkan keaktifan dan hasil belajar, karena siswa akan lebih aktif dalam berpikir dan memahami materi secara berkelompok dan siswa dapat lebih mudah menyerap materi pelajaran, serta kematangan pemahaman terhadap materi pelajaran. Dalam kajian ini peneliti tertarik untuk melakukan penelitian tindakan kelas dengan judul: "PENERAPAN PEMBELAJARAN STRATEGI PROBLEM BASED LEARNING (PBL) UNTUK MENINGKATKAN KEAKTIFAN DAN HASIL 


\section{BELAJAR IPA / BIOLOGI BAGI SISWA KELAS XI AK 1 SMK NEGERI 1 BANYUDONO KABUPATEN BOYOLALI SEMESTER GENAP TAHUN AJARAN 2011/2012".}

\section{Perumusan Masalah}

Apakah melalui strategi pembelajaran Problem Based Learning (PBL) dapat meningkatkan keaktifan dan hasil belajar IPA/BIOLOGI bagi siswa kelas XI AK 1 SMK N 1 Banyudono Kabupaten Boyolali Semester genap tahun ajaran 2011/2012?

\section{Tujuan Penelitian}

Untuk meningkatkan keaktifan dan hasil belajar IPA/BIOLOGI melalui strategi pembelajaran Problem Based Learning (PBL) bagi siswa kelas XI AK 1 SMK N 1 Banyudono Kabupaten Boyolali Semester genap tahun ajaran 2011/2012.

\section{Landasan Teori}

\section{Pengertian Belajar}

Belajar adalah suatu proses usaha yang dilakukan seseorang untuk memperoleh suatu perubahan tingkah laku yang baru secara keseluruhan, sebagai hasil pengalamannya sendiri dalam interaksi dengan lingkungannya (Slameto, 2003:2).

\section{Strategi Problem Based Learning (PBL)}

Strategi pembelajaran adalah cara-cara yang akan digunakan oleh pengajar untuk memilih kegiatan belajar yang akan digunakan selama proses pembelajaran. Pemilihan tersebut dilakukan dengan mempertimbangkan situasi dan kondisi, sumber belajar, kebutuhan dan karakteristik peserta didik yang dihadapi dalam rangka mencapai tujuan pembelajaran tertentu. Hubungan antara strategi, tujuan, dan metode pembelajaran dapat digambarkan sebagai satu kesatuan sistem yang bertitik tolak dari penentuan tujuan pembelajaran, pemilihan strategi pembelajaran, dan perumusan tujuan, yang kemudian diimplementasikan ke dalam berbagai metode yang relevan selama proses pembelajaran berlangsung (Hamzah, 2007:3).

Savoie dan Hughes (dalam Wena, 2009:91) menyatakan bahwa strategi belajar berbasis masalah memiliki karakteristik-karakteristik sebagai berikut: 1 . belajar dimulai dari suatu masalah; 2 . memastikan bahwa permasalahan yang diberikan berhubungan dengan dunia nyata siswa; 3. mengorganisasikan pelajaran di seputar permasalahan, bukan di seputar disiplin ilmu; 4. memberikan tanggung jawab sepenuhnya kepada pebelajar dalam mengalami secara langsung proses belajar mereka sendiri; 5. menggunakan kelompok kecil; dan 6 . menuntut pebelajar untuk mendemonstrasikan apa yang telah mereka pelajari dalam bentuk produk atau kinerja (performance).

Berdasarkan uraian tersebut tampak jelas bahwa pembelajaran dengan model PBL dimulai oleh adanya masalah (dapat dimunculkan oleh siswa atau guru), kemudian siswa memperdalam pengetahuannya tentang apa yang mereka telah ketahui dan apa yang mereka perlu ketahui untuk memecahkan masalah tersebut. Siswa dapat memilih masalah yang dianggap menarik untuk dipecahkan sehingga mereka terdorong berperan aktif dalam belajar.

Model pembelajaran Problem Based Learning memiliki beberapa kelebihan dan kelemahan. Kelebihan pembelajaran berdasarkan masalah sebagai suatu model pembelajaran adalah: 1). Realistik dengan kehidupan siswa; 2). Konsep sesuai dengan kebutuhan siswa; 3). Memupuk sifat inquiry siswa; 4). Retensi konsep menjadi kuat; 5). Memupuk kemampuan problem solving. Selain itu, kekurangannya adalah: a). Persiapan pembelajaran (alat, problem, konsep) yang kompleks; b). Sulitnya mencari problem yang relevan; c). Sering terjadi misskonsepsi; d). Memerlukan waktu yang cukup panjang (Widyastuti, 2010).

\section{Keaktifan Belajar}

Keaktifan belajar adalah aktifitas yang bersifat fisik maupun mental (Sardiman: 2001: 99). Selama kegiatan belajar kedua aktifitas tersebut harus terkait, sehingga akan menghasilkan aktifitas belajar yang optimal. Macammacam keaktifan belajar yang dapat dilakukan oleh siswa di sekolah antara lain : (1) Visual Activities, seperti : membaca, memperhatikan gambar, memperhatikan demonstrasi orang lain ; (2) Oral Activities, seperti : mengatakan , merumuskan, bertanya, memberi saran, mengeluarkan pendapat, mengadakan interview, diskusi interupsi ; (3) Listening Activities, seperti : mendengarkan : uraian, percakapan, diskusi, pidato ; (4) Writing Activities, seperti : menulis : ceritera, karangan, laporan, tes, angket, menyalin; (5) Drawing Activities, seperti : membuat : grafik, peta, diagram ; (6) Motor Activities, seperti : melakukan percobaan, membuat konstruksi model, mereparasi ; (7) Mental Activities, seperti : menanggapi, mengingat, memecahkan soal, menganalisa, melihat hubungan, mengambil keputusan ; (8) Emotional Activities, seperti : menaruh minat, merasa bosan, berani, gembira, gugup, senang .

\section{Hasil Belajar}

Hasil belajar tampak sebagai terjadinya perubahan tingkah laku pada diri siswa, yang dapat diamati dan diukur dalam bentuk perubahan pengetahuan sikap dan keterampilan. Perubahan tersebut dapat diartikan terjadinya peningkatan dan pengembangan yang lebih baik dibandingkan dengan sebelumnya, misalnya dari tidak tahu menjadi tahu, sikap kurang sopan menjadi sopan, dan sebagainya (Hamalik, 2008:155). Hasil belajar siswa pada hakikatnya adalah perubahan tingkah laku yang mencakup bidang kognitif, afektif, dan psikomotoris.

Tabel 1. Revisi ranah kognitf

\begin{tabular}{ccc}
\hline C1 & Knowledge & Remember \\
\hline C2 & Understand & Understand \\
C3 & Apply & Apply \\
C4 & Analyze & Analyze \\
C5 & Synthesis & Evaluate \\
C6 & Evaluate & Create \\
\hline
\end{tabular}

Sumber: Tatang, 2010 
Tabel di atas menunjukkan secara singkat perbedaan C1 sampai dengan C6 setelah melalui revisi. Setiap kategori dalam revisi taksonomi Bloom terdiri dari subkategori yang memiliki kata kunci berupa kata yang berasosiasi dengan kategori tersebut.

\section{Kerangka Berpikir}

Keberhasilan proses belajar mengajar dipengaruhi oleh faktor penggunaan strategi yang tepat. Dalam kegiatan belajar mengajar, pendekatan yang dilakukan oleh guru berpengaruh terhadap aktivitas belajar siswa.

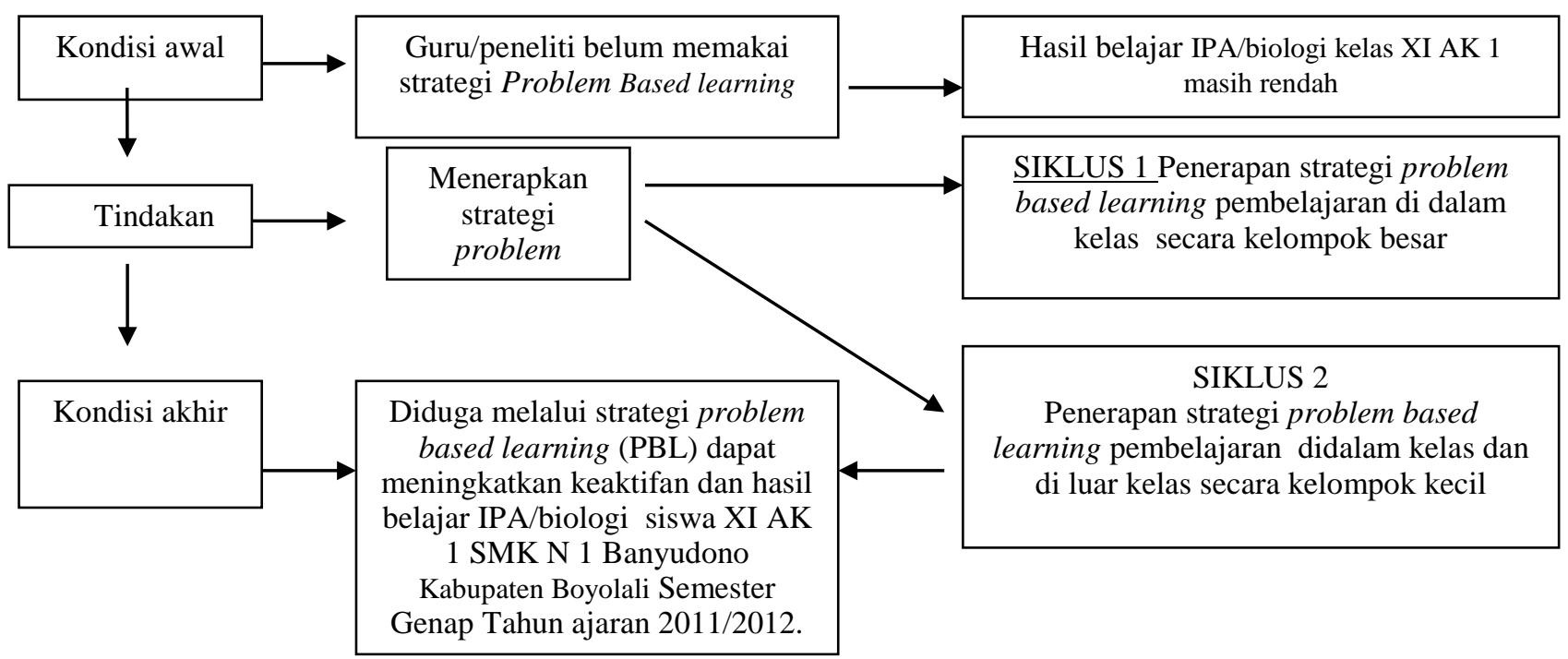

Gambar 1. Kerangka Pemikiran

\section{METODE}

\section{Objek/Subyek/Setting Tindakan}

Objek Penelitian ini adalah keaktifan dan hasil belajar IPA/BIOLOGI. Penelitian ini dilakukan dalam kurun waktu 6 bulan yaitu Desember 2011 hingga Mei 2012 dan tempat penelitiannya di SMK Negeri 1 Banyudono, kelas XI AK 1 sebanyak 40 siswa pada semester genap tahun pelajaran 2011/2012.

\section{Sumber Data}

1. Sumber data primer berasal dari subjek penelitian yaitu siswa didapat melalui pengamatan/observasi dan hasil ulangan harian. Adapun bentuk data yang diperoleh dalam bentuk kuantitatif maupun kualitatif.

2. Sumber data sekunder diperoleh dari data hasil pengamatan yang dilakukan oleh teman sejawat/kolaborasi.

\section{Teknik dan Alat Pengumpulan Data}

Teknik pengumpulan data

Penelitian tindakan kelas kali ini mengunakan teknik sebagai berikut :

1. Data kondisi awal : menggunakan teknik observasi untuk mendapatkan data keaktifan dan teknik tes untuk mendapatkan data hasil belajar sebelum menggunakan strategi Problem based learning (PBL).

2. Data siklus 1 : menggunakan teknik observasi untuk mendapatkan data keaktifan siswa dan teknik tes untuk mendapatkan data hasil belajar pada siklus 1 .
3. Data siklus 2 : mengunakan teknik observasi untuk mendapatkan data keaktifan siswa dan teknik tes untuk mendapatkan data hasil belajar pada siklus 2 .

Alat pengumpulan data

Dalam penelitian ini alat pengumpulan data adalah sebagai berikut:

1. Data kondisi awal:

a) Keaktifan belajar menggunakan teknik lembar observasi

b) Hasil belajar menggunakan butir-butir soal (tes tertulis).

2. Data siklus 1:

a) Keaktifan belajar mengunakan teknik lembar observasi

b) Hasil belajar menggunakan butir-butir soal (tes tertulis)

3. Data siklus 2:

a) Keaktifan belajar menggunakan teknik lembar observasi

b) Hasil belajar menggunakan butir-butir soal (tes tertulis)

Secara garis besarnya dalam penelitian ini ada 2 teknik yang digunakan yaitu :

1. Teknik tes : melalui butir soal tes

2. Teknik non tes : berbentuk pedoman dan lembar observasi.

\section{Validasi Data}

Penelitian ini untuk mendapatkan data yang valid maka diperlukan validasi data:

1. Keaktifan dan hasil belajar IPA/BIOLOGI pada kondisi awal maka validasi datanya menggunakan: (a) Keaktifan menggunakan teknik observasi dengan 
triangulasi sumber dengan sumber dari siswa, peneliti dan teman sejawat; (b) hasil belajar menggunakan teknik tes dengan dilengkapi kisi-kisi soal.

2. Keaktifan dan hasil belajar IPA/BIOLOGI pada siklus I maka validasi datanya menggunakan: (a) Keaktifan menggunakan teknik observasi dengan triangulasi sumber dengan sumber dari siswa, peneliti dan teman sejawat; (b) hasil belajar menggunakan teknik tes dengan dilengkapi kisi-kisi soal.

3. Keaktifan dan hasil belajar IPA/BIOLOGI pada siklus II maka validasi datanya menggunakan: (a) Keaktifan menggunakan teknik observasi dengan triangulasi sumber dengan sumber dari siswa, peneliti dan teman sejawat; (b) Hasil belajar menggunakan teknik tes dengan dilengkapi kisi-kisi soal.

\section{Analisis Data}

Dalam penelitian ini menggunakan analisis diskriptif komparatif yaitu

1. Membandingkan keaktifan belajar IPA/BIOLOGI kondisi awal, keaktifan belajar kondisi setelah siklus 1 dan keaktifan belajar setelah siklus 2, kemudian dilanjuktan refleksi: menarik kesimpulan berdasarkan deskriftif komparatif, membuat ulasan berdasarkan simpulan dan menentukan tindak lanjut.

2. Membandingkan hasil belajar IPA/BIOLOGI kondisi awal, hasil belajar setelah siklus 1 dan hasil belajar siklus 2, kemudian dilanjuktan refleksi: menarik kesimpulan berdasarkan deskriftif komparatif, membuat ulasan berdasarkan simpulan dan menentukan tindak lanjut.

\section{Indikator Kinerja}

Hasil belajar sebelumnya mencapai nilai rata-rata ulangan harian 70, setelah menggunakan metode PBL dapat mencapai indikator kinerjanya menjadi 75 , serta dari keaktifan belajar pada awalnya presentasenya rendah mengalami peningkatan yang signifikan.

\section{Prosedur Tindakan}

Dalam penelitian ini menggunakan langkah-langkah peneliti sebagai berikut :

Langkah pertama metode yang digunakan dalam penelitian tindakan kelas kali ini adalah menggunakan metode observasi dan tes. Langkah selanjutnya berupa banyaknya tindakan yang dilakukan dalam siklus kali ini sebanyak 2 siklus.

Adapun tahapan-tahapan dalam setiap siklus, terdiri dari 4 tahapan:

Siklus 1 terdiri dari 4 tahapan yaitu :

1. Siklus 1

a) Perencanaan tindakan meliputi : Apresepsi, kegiatan inti, penutup

b) Pelaksanaan tindakan

c) Tindakan yang dilakukan pada siklus 1 yaitu pembelajaran dengan strategi Problem based learning (PBL) pada pembelajaran di dalam kelas dengan kelompok besar, setiap kelompok terdiri dari 10 siswa sehingga akan terbentuk 4 kelompok dengan materi dampak polusi terhadap kesehatan manusia dan lingkungan.

d) Pengamatan

1) Yang diamati atau diobservasi adalah proses jalannya kegiatan belajar mengajar dengan menerapkan strategi Problem based learning (PBL).

2) Dalam penelitian tindakan kelas di sini yang dijadikan subjek adalah siswa kelas XI AK 1 dengan jumlah siswa dalam penelitian kali ini adalah 40 siswa.

3) Pengamatan dilakukan selama 3 kali pertemuan pada siklus 1

4) Hasil yang akan diperoleh dari observasi berupa data keaktifan tiap-tiap personal pada kelompok tersebut dan hasil belajar dari kegiatan pembelajaran pada siklus 1

e) Refleksi

Melakukan refleksi pada proses pembelajaran dan hasil belajar pada siklus 1 untuk ditindak lanjuti.

2. Siklus 2

a) Perencanaan tindakan meliputi : Apresepsi, kegiatan inti, penutup

b) Pelaksanaan tindakan

Tindakan yang dilakukan pada siklus 2 yaitu pembelajaran dengan menerapkan strategi Problem based learning (PBL) didalam kelas dan diluar kelas pada kelompok kecil, setiap kelompok terdiri dari 5 siswa sehingga akan terbentuk 8 kelompok dengan materi cara-cara pengelolaan limbah.

c) Pengamatan

1) Yang diamati atau diobservasi adalah proses jalannya kegiatan belajar mengajar dengan menerapkan strategi Problem based learning (PBL).

2) Dalam penelitian tindakan kelas di sini yang dijadikan subjek adalah siswa kelas XI AK 1 sebanyak 40 siswa.

3) Pengamatan dilakukan selama 4 kali pertemuan pada siklus 2

4) Hasil yang akan diperoleh dari observasi berupa data keaktifan tiap-tiap personal pada kelompok tersebut dan hasil belajar dari kegiatan pembelajaran pada siklus 2

d) Refleksi

Melakukan refleksi pada proses pembelajaran dan hasil belajar pada siklus 2 untuk ditindak lanjuti.

\section{HASIL TINDAKAN DAN PEMBAHASAN}

\section{Deskripsi Data Penelitian setiap siklus}

Deskripsi keaktifan belajar IPA/BIOLOGI

Selama proses belajar mengajar IPA/BIOLOGI pada kondisi awal keaktifan siswa masih kurang, masih banyak siswa yang hanya mendengarkan penjelasan guru tanpa ada yang menanyakan masalah-masalah materi yang sekiranya belum paham, bila diberi materi diskusi yang 
berbicara juga hanya siswa-siswa tertentu sehingga belum semua siswa aktif dalam proses pembelajaran tersebut.

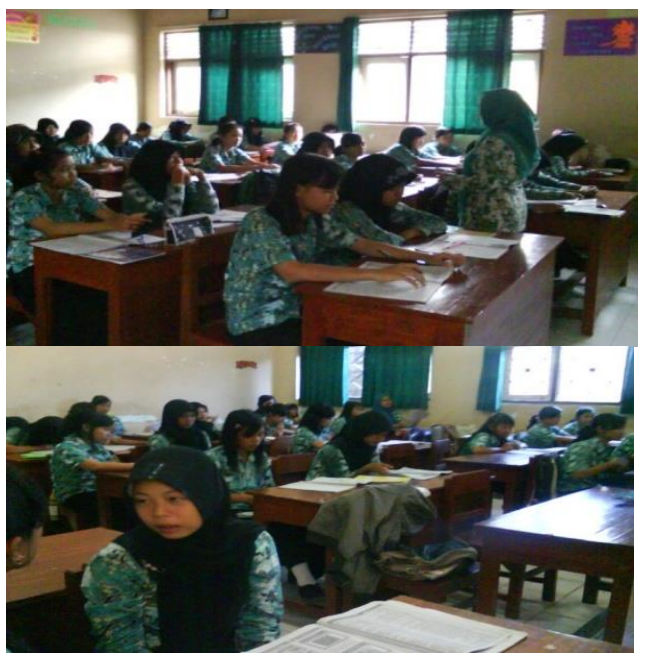

Gambar 3. Situasi pembelajaran konvensional

Penelitian Tindakan Kelas selama dua siklus telah menghasilkan data keaktifan siswa siswa kelas XI AK 1 di SMK N 1 Banyudono Kabupaten Boyolali semester genap Tahun ajaran 2011/2012.

\section{Keaktifan Siswa siklus I}

Sesuai dengan data selama penerapan strategi pembelajaran based learning atau pembelajaran berbasis masalah, pada siklus I, diperoleh presentase keaktifan siswa sebesar $69,2 \%$.

\section{Keaktifan siswa siklus II}

Sesuai dengan data selama penerapan strategi pembelajaran based learning atau pembelajaran berbasis masalah, pada siklus II , diperoleh presentase keaktifan siswa sebesar $76,3 \%$.

\section{Data Hasil Belajar}

Sesuai dengan hasil penelitian telah diperoleh data presentase hasil belajar siswa XI AK 1 di SMK Negeri 1 Banyudono Kabupaten Boyolali, semester genap tahun pelajaran 2011/2012.

Deskripsi data penelitian sebagai berikut :

1. Hasil belajar sebelumnya (kondisi awal)

Berdasarkan data hasil belajar dengan metode ceramah yaitu sebelum dilakukan siklus I diperoleh hasil belajar dengan nilai terendah 55 dan tertinggi 90 sedangkan jumlah siswa yang tuntas belajar 37 orang dan ketuntasan belajar klasikal 92,5\%. Dengan KKM 65 .

\section{Hasil belajar siklus I}

Sesuai dengan data hasil belajar setelah siklus I diperoleh prestasi terendah 60 dan tertinggi 90 dengan jumlah siswa yang tuntas 38 orang serta ketuntasan belajar klasikal 95 \%. Dengan KKM 65.
3. Hasil belajar siklus II

Hasil belajar siklus II diperoleh prestasi terendah 80 dan tertinggi 100 dengan jumlah siswa yang tuntas 40 orang serta ketuntasan belajar klasikal $100 \%$. Dengan KKM 65. Ketuntasan belajar klasikal selama tiga siklus dapat dilihat pada tabel 3 .

Tabel 2. Ketuntasan Belajar klasikal mata pelajaran IPA/BIOLOGI, standar kompetensi memahami polusi dan dampaknya pada manusia dan lingkungannya.

\begin{tabular}{ccccc}
\hline \multirow{2}{*}{$\mathrm{N}$} & Pelaksanaan & \multicolumn{2}{c}{$\begin{array}{c}\text { siswa yang tuntas } \\
\text { belajar }\end{array}$} & \\
\cline { 3 - 4 } & & $\begin{array}{c}\text { Jumlah } \\
\text { (orang) }\end{array}$ & $\begin{array}{c}\text { Presen- } \\
\text { tase }\end{array}$ & \\
\hline 0 & Sebelum Siklus I & 37 & $92,50 \%$ & $\begin{array}{c}- \\
\text { Meningkat } \\
2,5\end{array}$ \\
1. & Setelah Siklus I & 38 & $95 \%$ & $\begin{array}{c}\text { Meningkat } \\
5\end{array}$ \\
2. & Setelah Siklus II & 40 & $100 \%$ & \\
\hline
\end{tabular}

Tabel 3. Hasil belajar klasikal mata pelajaran IPA/BIOLOGI, standar kompetensi memahami polusi dan dampaknya pada manusia dan lingkungannya.

\begin{tabular}{cccccc}
\hline N & Pelaksanaan & $\begin{array}{c}\text { Teren- } \\
\text { dah }\end{array}$ & $\begin{array}{c}\text { Nillai } \\
\text { Ter- } \\
\text { tinggi }\end{array}$ & Maen & $\begin{array}{c}\text { K } \\
\text { et. }\end{array}$ \\
\hline 1. & Sebelum Siklus I & 55 & 90 & 81,25 & \\
2. & Setelah Siklus I & 60 & 90 & 81,125 & \\
3. & Setelah Siklus II & 80 & 100 & 93,5 & \\
\hline
\end{tabular}

Pelaksanaan diskusi kelompok sebagai aplikasi penerapan pembelajaran problem based learning (pembelajaran berbasis masalah ) dapat dilihat pada Gambar 4 dan Gambar 5.

1. Pelaksanaan pembelajaran Siklus I
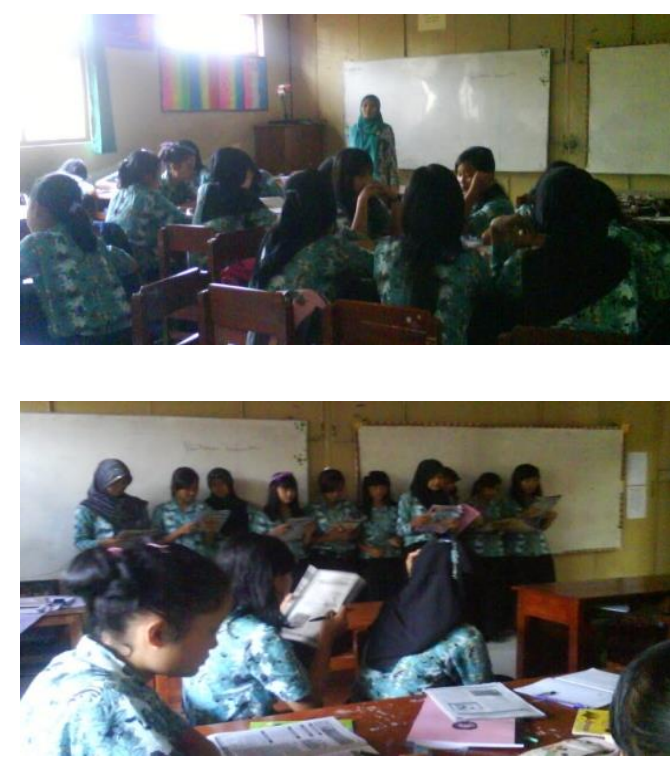

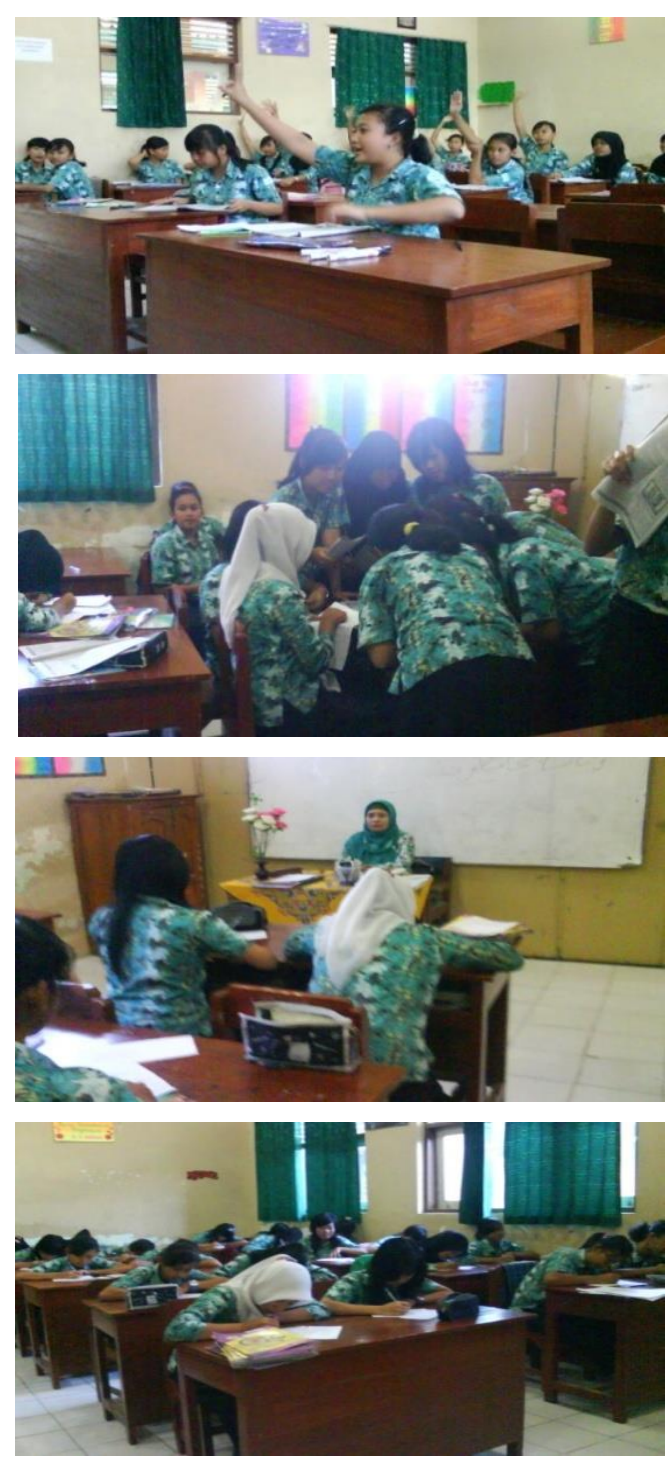

Gambar 4. Kegiatan Pembelajaran Siklus I

Pada pelaksanaan Evaluasi Standar kompetensi memahami polusi dan dampaknya pada manusia dan lingkungannya materi Dampak Polusi Terhadap Kesehatan Manusia dan Lingkungan, untuk mengukur hasil belajar siswa kelas XI AK 1.

2. Pelaksanaan pembelajaran Siklus II

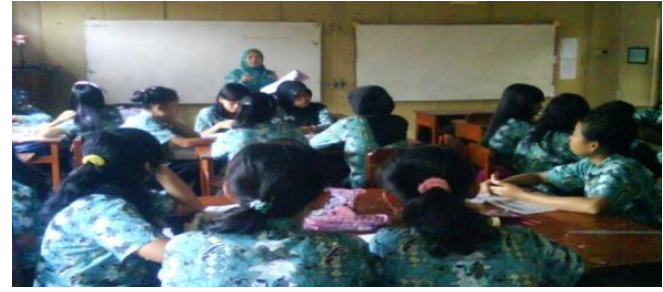

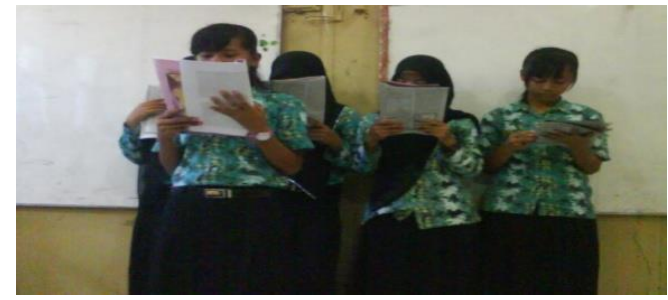
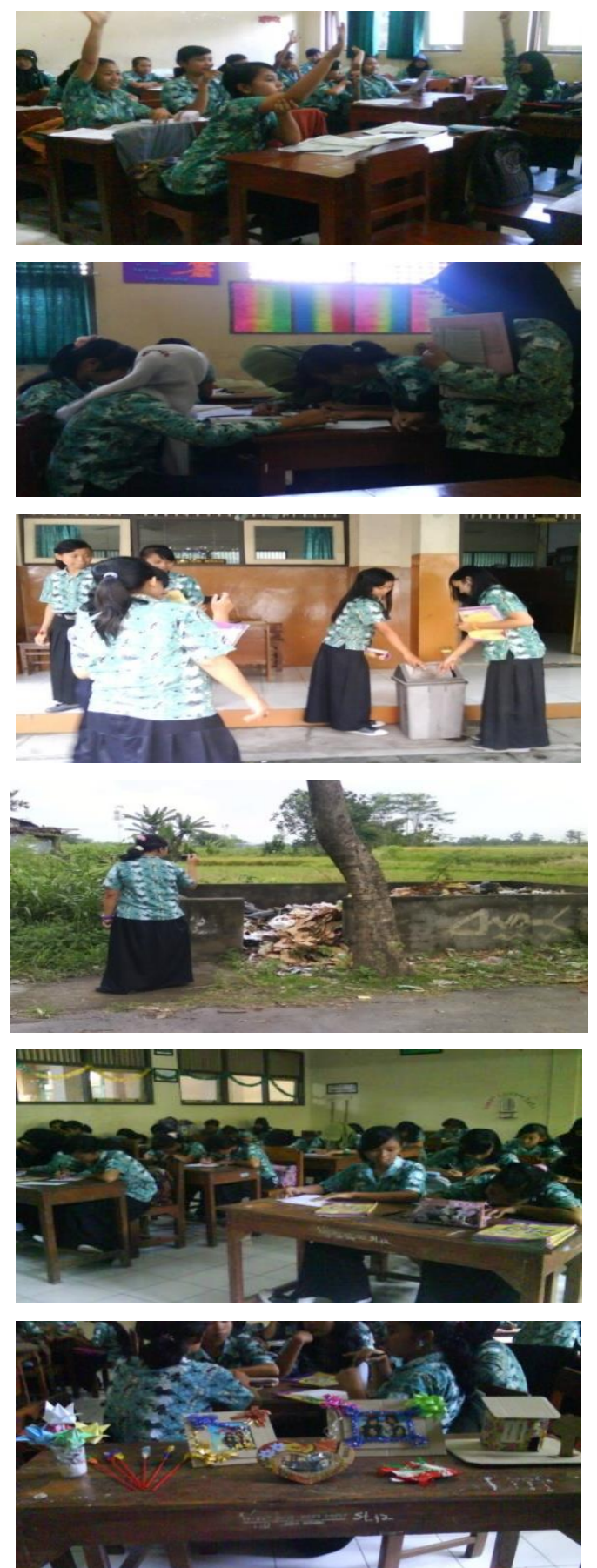

Gambar 5. Kegiatan Pembelajaran siklus II

Uji Hipotesis

Sesuai dengan ketuntasan belajar klasikal mata pelajaran IPA/BIOLOGI, Standar kompetensi memahami polusi 
dan dampaknya pada manusia dan lingkungannya materi Dampak Polusi Terhadap Kesehatan Manusia dan Lingkungan serta cara-cara penanganan limbah, siswa kelas XI AK 1, yang diperoleh tersebut kemudian diolah dengan menggunakan rumus ketuntasan belajar klasikal yang hasilnya sebagai berikut :

1. Hasil Perhitungan

a) Hasil perhitungan sebelum siklus I diperoleh ketuntasan belajar klasikal sebanyak 37 orang dari 40 siswa atau sebesar 92,5\%. Oleh karena itu telah mencapai batas minimal secara klasikal yaitu $85 \%$.

b) Hasil perhitungan setelah siklus I diperoleh ketuntasan belajar klasikal sebanyak 38 orang dari 40 siswa atau sebesar 95\%. Oleh karena itu telah mencapai batas minimal secara klasikal yaitu $85 \%$, maka penelitian dilanjutkan ke siklus II.

c) Hasil perhitungan setelah siklus II diperoleh ketuntasan belajar klasikal sebanyak 40 orang dari 40 siswa atau sebesar $100 \%$. Oleh karena itu telah mencapai batas minimal secara klasikal yaitu $85 \%$, maka penelitian tidak perlu dilanjutkan ke siklus berikutnya.

2. Kesimpulan

Berdasarkan hasil ketuntasan belajar klasikal dari siklus I sampai dengan siklus II telah terjadi peningkatan hasil belajar dan peningkatan keaktifan dalam memecahkan permasalahan, yang secara menyeluruh dinyatakan signifikan, maka dapat diambil kesimpulan Hipotesis dapat diterima kebenaranya. Diterima kebenarannya hipotesis yang diajukan tersebut diperkuat dengan maen (rata-rata) nilai hasil belajar siswa yang selalu meningkat setelah penerapan model pembelajaran kooperatif problem baced learning selama pembelajaran, yaitu : sebelum siklus I 81,25 , pada siklus II 81,125 dan pada siklus II 93,5 dan peningkatan keaktifan belajar Keaktifan Siswa siklus I diperoleh presentase keaktifan siswa sebesar 69,2 $\%$ dan siklus II diperoleh presentase keaktifan siswa sebesar $76,3 \%$.

Keadaan ini kelak akan memberikan dukungan terhadap upaya siswa untuk meningkatkan ketuntasan belajar pada standar kompetensi memahami polusi dan dampaknya pada manusia dan lingkungannya materi Dampak Polusi Terhadap Kesehatan Manusia dan Lingkungan serta cara-cara penanganan limbah sebagai bagian untuk diterapkan dalam kehidupan sehari-hari sebagai Life Skill. Oleh sebab itu, dalam usaha peningkatan keaktifan dan hasil belajar siswa, memerlukan kerja sama yang baik antara siswa dengan guru dan orang-orang yang terdekat dengan siswa.

\section{KESIMPULAN}

1. Penelitian Tindakan Kelas yang telah dilakukan, maka dapat disimpulkan sebagai berikut : Berdasarkan hasil ketuntasan belajar klasikal dari siklus I sampai dengan siklus II telah terjadi peningkatan hasil belajar dan peningkatan keaktifan dalam memecahkan permasalahan, yang secara menyeluruh dinyatakan signifikan, diperkuat dengan maen (rata-rata) nilai hasil belajar siswa yang selalu meningkat setelah penerapan model pembelajaran kooperatif problem baced learning selama pembelajaran, yaitu : sebelum siklus I 81,25, pada siklus II 81,125 dan pada siklus II 93,5 dan peningkatan keaktifan Siswa siklus I diperoleh presentase keaktifan siswa sebesar 69,2\% dan siklus II diperoleh presentase keaktifan siswa sebesar 76, 3\%. Penerapan model pembelajaran Kooperatif Problem based learning atau pembelajaran berbasis masalah secara signifikan dapat mendorong siswa untuk belajar lebih giat, bekerjasama dan berani tampil mengemukakan pendapat, telah terbukti kebenarannya.

\section{IMPLIKASI HASIL PENELITIAN}

Sesuai dengan hasil penelitian, ternyata bahwa penerapan model pembelajaran Kooperatif Problem based learning atau pembelajaran berbasis masalah lebih efektif untuk mencapai ketuntasan belajar klasikal, oleh karena itu semakin baik dan konsisten penerapan model pembelajaran Kooperatif Problem based learning atau pembelajaran berbasis masalah dalam pembelajaran akan memberikan kesempatan kepada setiap siswa untuk meningkatkan ketuntasan belajar sehingga dapat mencapai batas ketuntasan belajar sebagai bagian untuk menunjukkan kinerja pengelolaan pembelajaran di SMK Negeri 1 Banyudono, Kabupaten Boyolali.

\section{SARAN}

Dalam Penelitian tindakan kelas (PTK), untuk meningkatkan keaktifan dan hasil belajar pada standar kompetensi memahami polusi dan dampaknya pada manusia dan lingkungannya di semester genap, maka penulis menyampaikan saran-saran sebagai berikut :

1. Untuk Guru

a. Mengidentifikasi siswa yang masih kesulitan memahami dan mendalami materi Dampak Polusi Terhadap Kesehatan Manusia dan Lingkungan serta cara-cara penanganan limbah.

b. Memberikan bimbingan kepada siswa untuk dapat aktif melaksanakan pembelajaran dengan penerapan model pembelajaran Kooperatif problem based learning dalam mata pelajaran IPA/BIOLOGI.

c. Memberikan bimbingan kepada siswa yang mengalami kesulitan memperoleh ketuntasan belajar sesuai dengan batas ketuntasan belajar.

d. Berkolaborasi dengan atasan dan guru lainnya untuk meningkatkan ketuntasan belajar.

2. Untuk Siswa

a. Meningkatkan motivasi belajar sehingga dapat mendukung memperoleh hasil belajar sesuai dengan batas ketuntasan belajar.

b. Memiliki keaktifan yang semakin baik dalam mengikuti pelaksanakan pembelajaran dengan penerapan model pembelajaran Kooperatif problem based learning, sehingga mendukung memperoleh ketuntasan belajar.

c. Berkonsultasi dengan teman atau guru apabila mengalami kesulitan memahami materi 
kompetensi, sehingga mempermudah memperoleh prestasi yang sesuai dengan tujuan belajar.

3. Untuk Peneliti Lainnya

Diharapkan hasil penelitian ini dapat menjadi bahan referensi dalam melakukan penelitian lebih lanjut untuk menentukan model pembelajaran yang lain dan penerapan faktor lain yang dapat mendukung peningkatan hasil belajar, sehingga melalui penelitian ini diharapkan antara peneliti akan dapat saling memberi dan menerima guna untuk meningkatkan hasil belajar.

\section{UCAPAN TERIMAKASIH}

Puji syukur alhamdulillah kehadirat Allah SWT atas limpahan rahmat, taufik dan hidayah-NYA sehingga penulis dapat menyelesaikan penelitian hingga menyelesaikan laporan ini. Pelaksanaan penelitian ini dapat berjalan dengan lancar berkat bantuan dari berbagai fihak. Oleh sebab itu, pada kesempatan ini kami mengucapkan banyak terima kasih kepada :

1. Dra. Nunik Sulastri Rahayu , M.Pd selaku Kepala SMK Negeri 1 Banyudono yang telah memberikan kesempatan kepada kami untuk mengadakan penelitian ini.

2. Pihak UNS yang telah memberikan kesempatan emas, sehingga termuatnya tulisan ini di Jurnal Bioedukasi Pendidikan Biologi FKIP UNS.

3. Para guru IPA SMK Negeri 1 Banyudono yang telah berpartisipasi dalam pelaksanaan tindakan penelitian ini

4. Para siswa kelas XII Keahlian Administrasi Perkantoran di SMK Negeri 1 Banyudono yang menjadi subjek penelitian ini dan berpartisipasi aktif selama pelaksanaan tindakan.

5. Semua pihak yang telah membantu kelancaran pelaksanaan penelitian ini

6. Semoga amal baik semua pihak diatas mendapat balasan berlipat ganda dari Allah SWT. Amin.

\section{DAFTAR PUSTAKA}

Anni, C. T. (2004). Psikologi Belajar. Semarang: UPT UNNES Press.

Anisa, N. (2009). Penerapan Model Pembelajaran "Problem Based Learning" untuk Meningkatkan Hasil Belajar dan Kreativitas Siswa (Studi Pada Siswa Kelas XI Jurusan APK-2 di SMK Negeri 1 Turen Pada Mata Diklat Mail Handling). Skripsi tidak diterbitkan. Program Studi Pendidikan Administrasi Perkantoran Fakultas Ekonomi Universitas Negeri Malang.

Arikunto, S. (2006). PTK (Penelitian Tindakan Kelas), Jakarta: Rineka Cipta.
Ernawati. (2008). Ilmu Pengetahuan Alam untuk SMK dan MAK Kelas XI. Jakarta: Erlangga.

Hamalik, O. (2007). Dasar-Dasar Pengembangan Kurikulum. Bandung: Remaja Rosdakarya.

(2008). Perencanaan Pengajaran Berdasarkan pendekatan Sistem, Jakarta: Bumi Aksara.

Hamzah, B. U. (2007). Model Pembelajaran Menciptakan Proses Belajar Mengajar yang Kreatif dan Efektif. Jakarta: Bumi Aksara.

Mirza. (2009), "Peningkatan hasil Belajar Biologi Pokok Bahasan Pencemaran Lingkungan dengan PTK melalui Perpaduan Metode Problem Based Learning dan Team Games Turnament Pada Siswa Kelas X SMA Al-Islam 2 Surakarta". Skipsi tidak diterbitkan. Universitas Muhammadiyah Surakarta.

Mulyasa. (2009). Praktik Penelitian tindakan Kelas. Bandung: Remaja Rosdakarya.

Muslich, M. (2009). Melaksanakan PTK Itu Mudah, Jakarta: Bumi Aksara.

Nurhadi. (2004). Kurikulum 2004. Jakarta: Gramedia Widyasarana Indonesia.

Nurhayati. (2009). Penerapan Model Pembelajaran Berbasis Masalah (Problem Based Learning) dengan Pembelajaran Kooperatif Model Jigsaw untuk Meningkatkan Hasil Belajar Siswa (Studi pada Siswa APK Kelas X SMK PGRI 2 Malang pada Mata diklat Bekerjasama dengan Kolega dan Pelanggan). Skipsi tidak diterbitkan. Jurusan Manajemen Program Studi Pendidikan Administrasi Perkantoran, FE. Universitas Negeri Malang.

Poerwodarminto. W.J.S. (1992). Kamus Besar Bahasa Indonesia. Balai Pustaka.

Sardiman, AM. (2001). Interaksi dan Motivasi Belajar Mengajar, Jakarta: Rajawali.

Slameto. (2003). Belajar dan Faktor-faktor yang Mempengaruhinya, Jakarta: PT Asdi Mahasatya.

Tatang. (2010). Revisi Taksonomi Bloom. Online. http://tatangmanguny.wordpress.com/2010/01/19/taksonom i-bloom-versi-baru/, diakses tanggal 12 Januari 2012.

Wena, M. (2009). Strategi Pembelajaran Inovatif Kontemporen, Jakarta: Bumi Aksara.

Widyastuti. (2010). Pendekatan Pembelajaran Berbasis Masalah dan Pendekatan Berbasis Konteks (Contextual Teaching and Learning), Online: http://unsri.ac.id/ widyastuti/pendidikan/pendekatan-pembelajaran-berbasismasalah-problem-based-learning-dan-pendekatan-pembelajaran-berbasis-konteks-contextual-teaching-and-learning/ mrdetail/14376/, diakses tanggal 25 Januari 2012. 